\title{
EU Citizenship, Access to "Social Benefits" and Third-Country National Family Members: Reflecting on the Relationship between Primary and Secondary Rights in Times of Brexit
}

\author{
Elise Muir*
}

\section{Introduction}

It is often observed that EU law is highly "constitutionalised". The embedding of many EU rights in its "constitutional charter", ${ }^{1}$ in other words the EU treaties, has two related effects. It allows for the granting of a high degree of protection to selected rights. Simultaneously, it limits the ability of the EU legal order to process disagreement on the content and scope of such rights through ordinary political channels. Academic writings regularly and critically examine the high level of legal protection afforded to economic rights in the EU, in particular the four freedoms. ${ }^{2}$

To date, little attention has been devoted to non-economic rights enshrined in EU constitutional norms. As illustrated by the reservations of the UK, Poland and the Czech Republic on the justiciability of the "Solidarity" Title of the Charter of Fundamental Rights of the European Union (Charter), owing to its Protocol $30,{ }^{3}$ the legal status of non-economic rights in the EU legal order is often lower than that of economic rights. Furthermore, and

* Prof. dr. Elise Muir, Head of the Institute for European Law and Visiting Professor at the College of Europe. Publication contributing to the RESHUFFLE project, supported by the European Research Council. I am most grateful to Gillian More as well as Jonathan Tomkin for valuable comments on at earlier draft.

1 Court of Justice, judgment of 23 April 1986, case 294/83, Parti écologiste "Les Verts" $v$ European Parliament, para. 23 .

2 E.g. Scharpf, F.W. (2009). The Double Asymmetry of European Integration; or: Why the EU Cannot Be a Social Market Economy. MPIfG Working Papers, no. 12, p. 5 .

3 Art. 2 of Protocol no. 3 o on the application of the Charter of Fundamental Rights of the European union to Poland and to the United Kingdom and Protocol on the application of the Charter of Fundamental Rights of the European Union to the Czech Republic, in Annex 1 of European Council Conclusions of 29-30 October 2009. 
precisely for that reason, the argument usually is that the legal rank of noneconomic rights should be upgraded to act as a counter-weight to EU economic rights. ${ }^{4}$

Yet, the EU 'constitutional charter' does include provisions protecting a number of non-economic rights, in particular those of EU citizens. These have been actively used over the past few years. How do these constitutional norms protecting non-economic rights 5 interact with related EU legislation in this field?

This chapter investigates the relationship between primary rights, understood as rights enshrined in the EU Treaties or in EU law having the same rank, and secondary rights, understood as rights enshrined in EU legislation, by analysing some of the most controversial aspects of EU citizenship law over the past few years. This will serve as a basis for reflection on how high-level political disagreement on such non-economic rights, ${ }^{6}$ as exemplified in the campaign in favour of Brexit, ${ }^{7}$ is addressed within the EU legal order.

\section{I.1 Mapping out the Constitutional and Legislative Framework for EU Citizenship Law}

At the outset, it is useful to briefly map out the key legal provisions and the relationship between them as provided in EU primary law. Art. 18 of the Treaty on the Functioning of the European Union (TFEU) prohibits any discrimination on grounds of nationality within the scope of application of the treaties and without prejudice to any special provisions contained therein. The scope of application of the treaty is inter alia determined by Art. 21, para. 1, TFEU on the EU citizens' right to move and reside freely, but this right is also subject to limitations and conditions laid down in the Treaties and measures adopted to give them effect (i.e. legislation for our purpose, as will be explained below). The same holds true for Art. 20 TFEU, which establishes EU citizenship, lists a

4 For recent overviews and critical discussions of the matter see: Garben, S. (2017). The Constitutional (Im)balance Between 'the Market' and 'the Social' in the European Union. European Constitutional Law Review 13 (1), pp. 23-61 and Schiek, D. (2017). Towards More Resilience for a Social EU - the Constitutionally Conditioned Internal Market. European Constitutional Law Review 13 (4), pp. 611-640.

5 The material scope of the research is defined by reference to the UK Settlement, see infra.

6 It is acknowledged that political disagreement also relates to economic rights; these however are not the focus of the present paper as explained above.

7 See for instance the thoughts of Barnard, C., and Butlin, S.F. (2018). The Future of Free Movement of Persons in the UK (Part 1). EU Law Analysis, available at eulawanalysis.blogspot.com/ 2018/o6/the-future-of-free-movement-of-persons.html, section Introduction. 
set of related rights and refers to the conditions and limits defined by the Treaty and by the measures adopted thereunder.

Adding to the constitutional dimension of EU citizens' rights, the prohibition of nationality discrimination within the scope of application of the treaties and without prejudice to any of their specific provisions is mentioned in the Charter in Art. 21, para. 2. The right to move and reside freely within the territory of the Member States is also "reaffirmed" as a fundamental right in Art. 45, para. 1, of the Charter. ${ }^{8}$ Interestingly for our discussion below, Art. 45, para. 2, of the Charter states that "freedom of movement and residence may be granted, in accordance with the treaties, to nationals of third countries legally resident in the territory of a Member State".

Art. 21 TFEU on EU citizenship has been read in conjunction with Art. 18, para. 1, TFEU to prohibit discrimination on the grounds of nationality against certain non-economic actors. ${ }^{9}$ It has also been asserted that "Union citizenship is destined to be the fundamental status of nationals of the Member States"10 and Art. 21, para. 1, TFEU is directly effective. ${ }^{11}$ The CJEU has repeated on multiple occasions that the treaty provisions on EU citizenship shall only be relied upon if it is not possible to rely on the economic freedoms, ${ }^{12}$ although it does not always examine the applicability of economic freedoms in detail before turning to Art. 21 TFEU. In the present analysis of the non-economic rights of EU citizens, much of our attention will be devoted to Art. 21, para. 1, TFEU. ${ }^{13}$ Furthermore, impediments to the right conferred by Art. 21 TFEU to move and reside freely within the territory of the Member States ought to be checked before relying on Art. 2O, para. 1, TFEU. ${ }^{14}$ Art. 2O, para. 1, TFEU is thus a "fall back" category to which little attention will be devoted in the present paper.

As will be further explained and as naturally derives from the wording of the treaty and Charter provisions thereby identified, the rights of non-economically active citizens are closely intertwined with EU legislation. The main legislative

8 E.g. Court of Justice, judgment of 7 October 2010, case C-162/o9, Secretary of State for Work and Pensions $v$ Taous Lassal, para. 29.

9 E.g. Court of Justice, judgment of 12 May 1998, case C-85/96, María Martínez Sala v Freistaat Bayern.

10 Court of Justice, judgment of 20 September 2001, case C-184/99, Rudy Grzelczyk v Centre public d'aide sociale d'Ottignies-Louvain-la-Neuve, para. 31.

11 Court of Justice, judgment of 17 September 2002, case C-413/99, Baumbast and $R v$ Secretary of State for the Home Department, para. 86.

12 Court of Justice, judgment of 12 March 2014, case C-457/12, S. and G., para. 45.

13 On the rights of economic migrants as provided for in the EU Treaties see: Arts 45, para. 2, 49, para. 1 , and 56 , para. 1 , TFEU.

14 Court of Justice, judgment of 5 May 2011, case C-434/o9, Shirley McCarthy, paras 48-49. 
instrument is Directive 2004/38 ${ }^{15}$ of the European Parliament and of the Council of 29 April 2004 on the right of citizens of the Union and their family members to move and reside freely within the territory of the Member States (Directive 2004/38). It amends and replaces a set of earlier instruments ${ }^{16}$ but it is the first legislative instrument designed to comprehensively regulate the rights of EU citizens as such. It also co-exists with Regulation 492/2011 (formerly 1612/68) of the European Parliament and of the Council on freedom of movement for workers within the EU.

Clarifying the relationship between the Directive, treaty provisions on citizenship and other legislative instruments, the CJEU made clear that Directive 2004/38 "aims to facilitate the exercise of the primary and individual right to move and reside freely within the territory of the Member States that is conferred directly on Union citizens by the Treaty and that it aims in particular to strengthen that right, so that Union citizens cannot derive fewer rights from that directive than from the instruments of secondary legislation which it amends or repeals". ${ }^{17}$ The CJEU has therefore given a distinctly positive and forward looking role to Directive 2004/38. The Directive is understood as a development on pre-existing legislation, giving expression to the primary citizenship rights. ${ }^{18}$

\section{I.2 The Multiple Constitutional Functions of Art. 21 TFEU}

The constitutional anchorage of EU citizens' rights as just briefly described has important implications. Treaty articles such as Art. $21 \mathrm{TFEU}$ perform three functions in the EU legal order. ${ }^{19}$ First, Art. 21 TFEU can be seen as a benchmark against which the activities of EU and national organs falling within the scope of EU law may be reviewed, and in light of which such activities must be interpreted. In that respect, this Treaty provision largely overlaps with relevant

15 Directive 2004/38/EC of the European Parliament and of the Council of 29 April 2004 on the right of citizens of the Union and their family members to move and reside freely within the territory of the Member States amending Regulation (EEC) No 1612/68 and repealing Directives 64/221/EEC, 68/36o/EEC, 72/194/EEC, 73/148/EEC, 75/34/EEC, 75/35/ EEC, 9o/364/EEC, 9o/365/EEC and 93/96/EEC, OJ L 158, 30.4.2004, p. 77-123.

16 As is clear from the title of Directive 2004/38 itself.

17 E.g. Secretary of State for Work and Pensions $v$ Taous Lassal, cit., para. 3o. See also Court of Justice, judgment of 25 July 2008, case C-127/08, Metock, para. 59 .

18 Note that a number of EU directives give expression to the fundamental right not to be discriminated against; see further: Muir, E. (2018). EU Equality Law: The First Fundamental Rights Policy of the EU. Oxford: Oxford University Press, Chapter IV.

19 Reflecting on the different functions on Treaty provisions on non-discrimination: Muir, E. (2018). EU Equality Law: The First Fundamental Rights Policy of the EU, cit., Chapter III.A. 
Charter provisions and corresponding general principles. In addition, Art. 21, para. 1, TFEU defines the scope and content of EU regulatory intervention in domestic policies to the extent that it is directly effective. ${ }^{20}$ Thirdly, Art. 21, para. 2, TFEU constitutes a legal basis for the adoption of further legislation. This multiplicity of functions distinguishes this source of rights and obligations from other categories of instruments which only perform some of these functions. This also explains why the dividing line between secondary legislation and primary rights in this field is not always clear, as will be further illustrated below.

Such ambivalence is not uncommon in the EU legal order. ${ }^{21}$ The normative content of the EU treaty performs the function of a constitutional benchmark (in the same way as the Charter). Meanwhile, as a 'derivative' legal order, ${ }^{22}$ the exercise of EU powers depends upon the allocation of specific competences so that the EU constitutional charter provides a set of provisions defining the scope of EU regulatory intervention. The process of European integration has resulted in embedding an atypical amount of normative content in the very same provisions that define the scope for EU regulatory intervention. This means that the scope and content of EU intervention are often actually merged, leading to the high level of constitutional protection mentioned above.

The existence or absence of legislation as referred to in the treaty provisions on citizenship may also mark the cut-off point of active intervention by the EU. The interpretation of the content and scope of legislation has direct implications on the relationship between domestic and EU competences. The judicial interpretation of the parameters of EU legislation giving expression to EU citizens' rights is a delicate exercise: the process by which political institutions have thought to circumscribe EU intervention may be reviewed against the very primary right that the legislation is intended to shape. The CJEU's views on the primary law version of the right at hand thus more ostensibly competes

20 On the first two functions, see Baumbast, cit., para 86: 'the application of the limitations and conditions acknowledged in Art. 18, para. 1, EC in respect of the exercise of that right of residence is subject to judicial review. Consequently, any limitations and conditions imposed on that right do not prevent the provisions of Art. 18, para. 1, EC from conferring on individuals rights which are enforceable by them and which the national courts must protect (see, to that effect, Court of Justice, judgment of 4 December 1974, case 41/74, Van Duyn, para. 7).

21 E.g. In relation to EU sex equality law see for instance Art. 157 TFEU; e.g. Hervey, T.K. (2005)., Thirty Years of EU Sex Equality Law: Looking Backwards, Looking Forwards. Maastricht Journal of European and Comparative Law 12 (4), pp. 307-325.

22 Walker, N. (2001). Human Rights in a Post-National Order: Reconciling Political and Constitutional Pluralism. In: T. Campbell, K. D. Ewing and A. Tomkins, eds., Sceptical Essays on Human Rights, Oxford: Oxford University Press, p. 129. 
with those expressed by political authorities. There is also a risk of hindering or swaying political debate by significantly interfering with the content and scope of rights defined in legislation through the interpretation of EU constitutional norms. In a derivative legal order such as that of the EU, the interpretation of legislation adopted at the supranational level therefore unquestionably raises questions of a constitutional nature.

As a consequence, by its very nature, Art. $21 \mathrm{TFEU}$ places the constituent powers and the CJEU as well as the EU legislature in a position to jointly drive EU citizenship forward. This form of institutional collaboration is particularly interesting as it relates to the fleshing out of the concept of EU citizenship that is intended to legitimise the edifice of the European Union. However, the way forward may be bumpy: How does EU law address disagreement on such a symbolic concept?

\section{I.3 Tensions between Primary and Secondary Law: the UK Settlement as an Illustration}

The Settlement for the UK from 2016 (UK Settlement) ${ }^{23}$ offered an occasion to test the relationship between the primary and secondary rights of EU citizens. It explored the boundaries of what could be adjusted within EU law in order to address the concerns of the UK with minimal constitutional impact. The nature of this exercise may remind us of similar sorts of "constitutional dialogues"24: such as that leading to the adoption of the Barber protocol ${ }^{25}$ or the insertion of Art. 157, para. 4, in the TFEU. ${ }^{26}$ Although the UK Settlement did not enter into force, ${ }^{27}$ it is the latest illustration of the ability to organise

23 Decision of the Heads of State or Government, meeting within the European Council, concerning a new settlement for the United Kingdom within the European Union, in Annex 1 of European Council Conclusions of 18-19 February 2016.

24 See further: Muir, E. (2018). EU Equality Law: The First Fundamental Rights Policy of the EU, cit., Chapter III.

25 Protocol no. 2 concerning Art. 119 of the Treaty Establishing the European Community. See further: Curtin, D. (1993). The Constitutional Structure of the Union: A Europe of Bits and Pieces. Common Market Law Review 30 (1), pp. 17-69.

26 It was inserted by the Treaty of Amsterdam, see also Declaration no. 28 on Art. 119(4) of the Treaty establishing the European Community. See Howard, E. (2008). The European Year of Equal Opportunities for All-2007: Is the EU Moving Away from a Formal Idea of Equality?. European Law journal 14 (2), pp. 168-185, 175-176; Maduro, M. (2005). La Cour de justice des Communautés européennes et la législation d'anti-discrimination. Revue du droit Européen Relatif à la Non-Discrimination, pp. 25 et seq.

27 Section E.2., of the Decision of the Heads of State or Government, meeting within the European Council, concerning a new settlement for the United Kingdom within the European Union, in Annex 1 of European Council Conclusions of 18-19 February 2016. 
a political response to challenges to EU citizens' rights within existing EU primary law. ${ }^{28}$ The UK Settlement therefore provides a most useful opportunity to reflect on the constitutional design of EU citizenship law. ${ }^{29}$

It is noteworthy that of the various controversial aspects of the debate surrounding the Brexit referendum and in the UK Settlement, two were related to the non-economic rights of EU citizens and tested the relationship between primary and secondary law in that respect - more specifically the relationship between Art. 21 TFEU and Directive 2004/38. These aspects will be the focus of the present chapter. Selected excerpts from the UK Settlement are reproduced here for the ease of the reader. ${ }^{30}$

The first aspect of the UK Settlement of interest to this paper ${ }^{31}$ relates to the rights of non-economically active persons and sought to address concerns about the burden on the social assistance system of the host Member State that these persons represent. Annex I, Section D on "Social benefits and free movement", point 1, of the UK Settlement reads as follows:

(b) Free movement of EU citizens under Article $21 \mathrm{TFEU}$ is to be exercised subject to the limitations and conditions laid down in the Treaties and the measures adopted to give them effect.

The right of economically non-active persons to reside in the host Member State depends under EU law on such persons having sufficient resources for themselves and their family members not to become a burden on the social assistance system of the host Member State, and on those persons having comprehensive sickness insurance.

Member States have the possibility of refusing to grant social benefits to persons who exercise their right to freedom of movement solely

28 The objective was 'to settle, in conformity with the Treaties, certain issues raised by the United Kingdom': Decision of the Heads of State or Government, meeting within the European Council, concerning a new settlement for the United Kingdom within the European Union, in Annex 1 of European Council Conclusions of 18-19 February 2016.

29 Case law developed exclusively on the basis of Treaty provisions is left aside as it leaves little room for interaction with legislation. See for instance the line of cases developed on the basis of Art. 20 TFEU and the ruling in Court of Justice, judgment of 8 March 2011, case C-34/o9, Zambrano. See also Court of Justice, judgment of 12 March 2019, case C-221/17, M.G Tjebbes et al. $v$ Minister van Buitenlandse Zaken.

30 Others related to the free movement of workers (e.g. the indexation of child benefits, alter and safeguard mechanism) and the notions of public policy or public security.

31 Other important aspects of the UK Settlement such as the safeguard mechanism related to in-work benefits for workers are not discussed in this paper devoted to the rights of non-economic actors. 
in order to obtain Member States' social assistance although they do not have sufficient resources to claim a right of residence. [...] (emphasis added)

The second aspect of the UK Settlement relates to the rights of third-country national family members of an EU citizen with no prior lawful residence, with a view to countering fears of circumvention of national immigration rules. Annex VII of the UK Settlement reads as follows:

The Commission intends to adopt a proposal to complement Directive $2004 / 38$ on free movement of Union citizens in order to exclude, from the scope of free movement rights, third country nationals who had no prior lawful residence in a Member State before marrying a Union citizen or who marry a Union citizen only after the Union citizen has established residence in the host Member State. Accordingly, in such cases, the host Member State's immigration law will apply to the third country national. This proposal will be submitted after the above Decision has taken effect [...] (emphasis added)

The two themes thereby addressed by the UK Settlement and related to Art. 21 TFEU provide interesting case studies for the purpose of examining the relationship between primary and secondary rights in the context of intense political disagreement on non-economic rights. The challenges thereby identified on the one hand, free movement of EU citizens v. fear of burdens on the social assistance system, and on the other, free movement of EU citizens v. national immigration law - have been framed in two different, if not opposing, ways in EU constitutional law.

On the one hand, on the issue of access to social benefits for noneconomically active persons (Section II), the case law of the CJEU has progressively proceeded to a "deconstitutionalisation" process (i.e. shifting attention from the right enshrined in primary law to the rights provided for in secondary law) on which the UK Settlement could subsequently comfortably rely. The UK Settlement could indeed rely on an interpretation of Directive 2004/38 which is favourable to the requests of the UK with little fear of breaching primary law.

On the other hand, the precise legal status of the rights of EU third-country national family members of EU citizens with no prior lawful residence was blurred. This allowed the UK Settlement to propose a political solution to address the claims of the UK - i.e. of a legislative nature - but case law suggests that this approach could be in breach of EU primary law. Indeed, the rights of 
third-country national family members of an EU citizen are seemingly protected by the EU Treaty rights as we shall see (Section III).

After spelling out the constitutional setting in relation to both types of rights, we will seek to draw lessons for the constitutional design of non-economic rights of EU citizens when treaty and legislation co-exist (Section IV). It will be argued that whenever possible, emphasis shall be placed on legislative guidance so as to allow for political dialogue.

\section{Deconstitutionalising the Perimeters of EU Citizenship Law: from} Martínez Sala to Brey et al. as Reflected in the UK Settlement

In a now well-known series of recent cases on the rights of mobile EU citizens that do not perform an economic activity, the CJEU "deconstitutionalised" its understanding of key aspects of the prohibition of nationality discrimination (enshrined in Art. 18, para. 1, TFEU). In other words, the CJEU moved the discussion to the secondary law level, having kept it at the primary law level for many years. ${ }^{32}$

\section{II.1 Enshrining EU Citizens' Rights in EU Primary Law: 'Constitutional Engineering'}

The story starts in the late 199os when the CJEU's ruling in Martínez Sala ${ }^{33}$ captured the imagination of lawyers by asserting that a mobile EU citizen ${ }^{34}$ "lawfully resident in the territory of the host Member State, can rely on [Art. 18 $\mathrm{TFEU}$ ] in all situations which fall within the scope ratione materiae of [Union] law" ${ }^{35}$ Furthermore, a situation would fall within the scope ratione materiae of Union law if the "Member State delays or refuses to grant to that claimant a benefit [covered by Regulations $1408 / 71^{36}$ and $1612 / 68^{37}$ ] that is provided to all

32 Elements of the following sections build on Muir, E. (2018). EU Equality Law: The First Fundamental Rights Policy of the EU, cit., Chapter III.B.2.c.ii.

33 María Martínez Sala v Freistaat Bayern, cit.

34 Ibid., para. 61.

35 Ibid., para. 63 .

36 Regulation (EEC) 1408/71 of the Council of 14 June 1971 on the application of social security schemes to employed persons and their families moving within the Community, OJ $L$ 149, 5.7.1971, p. 2-50.

37 Regulation (EEC) 1612/68 of 15 October 1968 of the Council on freedom of movement for workers within the Community, OJ L 257, 19.10.1968, p. 2-12. Please note that this regulation has now been repealed by Regulation (EU) No 492/2011 of the European Parliament and of the Council of 5 April 2011 on freedom of movement for workers within the Union, OJ L 141, 27.5.2011, p. 1-12. 
persons lawfully resident in the territory of that State on the ground that the claimant is not in possession of a document which nationals of that same State are not required to have and the issue of which may be delayed or refused by the authorities of that State". ${ }^{38}$

The CJEU thereby decoupled the personal scope of the EU prohibition of nationality discrimination from specific requirements established by EU legislative instruments regulating its material scope. ${ }^{39}$ It was now enough to be an EU citizen lawfully residing in another Member State under the law of that Member State ${ }^{40}$ to benefit from the prohibition of nationality discrimination (Art. 18, para. 1, TFEU), in order to obtain a benefit covered by specific EU legislation. This was remarkable progress for non-economically active and mobile EU citizens. Before that, their equal treatment rights did not have constitutional status in EU law and only legislative instruments setting specific ratione personae requirements applied to them before they could be granted a limited set of rights. ${ }^{41}$ This framed the debate on EU mobile and non-economically active citizens' equal treatment rights in constitutional terms, despite the provision in the treaty articles on EU citizenship (Arts 20, para. 2, and 21, para. 1, $\mathrm{TFEU}$ ) and the general prohibition of nationality discrimination (Art. 18, para. $1, \mathrm{TFEU}$ ) referring to the limits of the Treaty and to its scope of application as possibly defined in legislation.

\section{II.2 The Adoption of New Legislation: Fresh Political Guidance}

In interpreting the principle of equal treatment for mobile EU citizens in such an innovative way, the CJEU limited the possibility for the EU legislature to influence the personal scope of the said principle. In 2004, the European Parliament and the Council adopted Directive 2004/38. ${ }^{42}$ According to this Directive and building on earlier legislative guidance, a pre-condition for a non-economically active person to have lawful residence for more than three months in another Member State under EU law is to have "sufficient resources for themselves and their family members not to become a burden on the social

$38 \quad$ María Martínez Sala v Freistaat Bayern, cit., para. 63.

39 Ibid., paras 45 and 56-62. See further O'Leary, S. (1999). Putting Flesh on the Bones of European Union Citizenship. European Law Review 24 (1), pp. 68-79, 77-78.

$40 \quad$ María Martínez Sala v Freistaat Bayern, cit., para. 47.

41 See Directive 9o/366/EEC of the Council of 28 June 1990 on the right of residence for students, OJ L 180, 13.7.199o, p. 30-31; Directive 9o/365/EEC of the Council of 28 June 1990 on the right of residence for employees and self-employed persons who have ceased their occupational activity, OJ L 180, 13.7.199o, p. 28-29 and Directive 9o/364/EEC of the Council of 28 June 1990 on the right of residence, OJ L 180, 13.7.199o, p. $26-27$. 
assistance system of the host Member State during their period of residence and have comprehensive sickness insurance cover in the host Member State".43

Lawful residents would then enjoy equal treatment on the ground of nationality; this was repeated in Art. 24, para. 1, of the Directive subject to certain conditions, including an exception to the effect that: "the host Member State shall not be obliged to confer entitlement to social assistance during the first three months of residence or, where appropriate, the longer period provided for in Article 14(4)(b) [establishing specific conditions for work seekers] to persons other than workers, self-employed persons, persons who retain such status and members of their families". ${ }^{44}$ In other words, the Member States' concern to protect their social assistance systems against overburdening influenced both the conditions to obtain lawful residence in another Member State under EU law and equal treatment rights.

Although the Directive was only to apply in the Member States from 2006, the provisions adopted could have prompted the Court to give greater emphasis to the Union legislature's attempt to circumscribe the conditions under which free movement rights could be exercised. Nevertheless, the CJEU continued to reason directly on the basis of Treaty provisions on issues concerned with equal treatment rights of mobile and non-economically active EU citizens. ${ }^{45}$ In doing so it largely disregarded the concern expressed by political institutions to make non-economically active migrants' residence - and therefore equal treatment rights under EU law - conditional upon having a "sufficient" level of resources. ${ }^{46}$

\section{II.3 Legislation Acting as a Gateway to EU Citizenship Rights}

A move away from the constitutional approach described in the past section and towards deconstitutionalisation, or greater emphasis being placed on

43 Art. 7, para. 1, let. b, of Directive 2004/38, cit.

44 Art. 24, para. 2, of Directive 2004/38, cit.

45 E.g. Court of Justice, judgment of 7 September 2004, case C-456/02, Trojani, para. 39 and Court of Justice, judgment of 15 March 2005, case C-209/o3, Bidar, para. 46. The position of the CJEU can usefully be contrasted to that of the Advocate General in that case: Opinion of AG Geelhoed delivered on 19 February 2004, case C-456/o2, Trojani. See further Van der Mei, A.P. (2005). Union Citizenship and the 'De-Nationalisation' of the Territorial Welfare State, Comments on Trojani (Case-456/o2 of 7 September 2004) and Bidar (Case C-209/ 03 of 15 March 2005). European Journal of Migration and Law 7 (2), pp. 203-211, 209.

46 Note that, and I am grateful to Gillian More for stressing this, there were also elements in the Directive intended to balance this approach such as Art. 14, para. 3, Directive 2004/38 according to which: 'An expulsion measure shall not be the automatic consequence of a Union citizen's or his or her family member's recourse to the social assistance system of the host Member State'. 
secondary legislation, was initiated by the Brey case of $2013 .{ }^{47}$ This redirection was confirmed in three subsequent cases. ${ }^{48}$ The characteristics of this new case law can be summarised as follows. To start with, the CJEU now declines to reason on the basis of treaty provisions on citizenship and nationality discrimination; it focuses instead almost exclusively on guidance provided in secondary legislation. Although this is visible in all four cases, ${ }^{49}$ it is particularly clear in Dano where the CJEU had been specifically asked to reason on the basis of EU constitutional law but refused to do so. The CJEU indeed raised the fact that the Charter could only be applied within the scope of Union law. As the situation was not covered by EU secondary legislation, this condition was not fulfilled in the case at hand. ${ }^{50}$ In other words, the CJEU refused to look at whether the treaty provisions on EU citizenship and nationality discrimination could bring the matter within the scope of EU law despite the limitations enshrined in secondary legislation. The CJEU further explained elsewhere in the ruling that protection of non-economically active mobile citizens against nationality discrimination when this occurred outside the scope of Directive 2004/38 would run counter to one of the Directive's objectives: to prevent such citizens from becoming an unreasonable burden on the social assistance system of the host Member State. ${ }^{51}$ In other words, the CJEU did a methodological U-turn on its earlier case law, whereby such equal treatment rights were granted to all with direct reference to the treaty provisions on nationality discrimination and EU citizenship.

Secondly, from the EU secondary law sources, the CJEU places particular emphasis on Directive 2004/38 which lays down - inter alia - the conditions governing the exercise of the right of free movement and residence within the territory of the Member States by EU citizens. ${ }^{52}$ Not only does this emphasis result from the move away from treaty provisions, but it can also be read as a

47 Court ofJustice,judgment of 19 September2013, caseC-140/12, Pensionsversicherungsanstalt $v$ Peter Brey.

48 Court of Justice, judgment of 11 November 2014, case C-333/13, Elisabeta Dano and Florin Dano v Jobcenter Leipzig; Court of Justice, judgment of 15 September 2015, case C-67/14, Jobcenter Berlin Neukölln v Nazifa Alimanovic and Others; Court of Justice, judgment of 25 February 2016, case C-299/14, Vestische Arbeit Jobcenter Kreis Recklinghausen v Jovanna García-Nieto and Others.

49 See for instance: Pensionsversicherungsanstalt $v$ Peter Brey, cit., paras $46-47$ and 53-56; Jobcenter Berlin Neukölln v Nazifa Alimanovic and Others, cit., para. 50; Vestische Arbeit Jobcenter Kreis Recklinghausen v Jovanna García-Nieto and Others, cit., para. 39.

$50 \quad$ Elisabeta Dano and Florin Dano v Jobcenter Leipzig, cit., para. 90.

$5^{1}$ Ibid., para. 74, see also paras 6o-62.

$5^{2}$ Art. 1, let. a), of Directive 2004/38, cit. 
clarification of certain aspects of the relationship between this Directive and Regulation $883 / 2004$ on the coordination of social security systems. ${ }^{53}$ Directive 2004/38 is given precedence when it comes to defining EU citizens' rights of residence in another Member State. ${ }^{54}$ As a consequence, the Directive acts as a gateway to EU equal treatment law on the grounds of nationality for noneconomic actors ${ }^{55}$ which, in the view of the CJEU, is indeed in line with one of the central objectives of the said Directive. ${ }^{56}$

Thirdly, in seeking guidance from Directive 2004/38, the CJEU sticks as closely as possible to the spirit, wording and gradual system established by it when possible. ${ }^{57}$ When no such specific scheme exists, the CJEU provides guidance to the competent national authorities on how to ensure compliance with the general requirements of the Directive after closely examining its overall internal dynamics. ${ }^{58}$ For instance, the Directive establishes that residence for more than three months ${ }^{59}$ and less than five years for non-economically active persons who do not have a more specific and beneficial status ${ }^{60}$ is dependent inter alia upon having "sufficient resources for themselves and their family members not to become a burden on the social assistance system of the host Member State". ${ }^{61}$ In Brey, the CJEU indicated that this must be understood as requiring "an overall assessment of the specific burden which [a national of another Member State requesting a particular social assistance benefit ${ }^{62}$ ] would place on the national social assistance system as a whole, by reference to the personal circumstances characterising the individual situation of the

53 Regulation (EC) 883/2004 of the European Parliament and of the Council of 29 April 2004 on the coordination of social security systems, OJ L 166, 30.4.2004, p. 1-123.

54 Pensionsversicherungsanstalt $v$ Peter Brey, cit., paras 50 and $53-54$.

55 Elisabeta Dano and Florin Dano v Jobcenter Leipzig, cit., para. 83; see also: Court of Justice, judgment of 14 June 2016, case C-308/14, European Commission v United Kingdom of Great Britain and Northern Ireland, para. 68. For critical comments on that approach see Verschueren, H. (2015). Preventing "Benefit Tourism" in the EU: a Narrow or Broad Interpretation of the Possibilities Offered by Dano. Common Market Law Review $5^{2}$ (2), pp. 363-39o, 377 et seq.

56 Art. 1, let. a), of Directive 2004/38, cit.

57 See Opinion of AG Wathelet delivered on 11 January 2018, case C-673/16, Coman.

58 E.g. Elisabeta Dano and Florin Dano v Jobcenter Leipzig, cit., paras 69-73 and 77 .

59 Note that in Brey the applicant for social benefits desired to reside for more than three months, see Pensionsversicherungsanstalt v Peter Brey, cit., para. 53 .

6o See the other recitals of Art. 7 of Directive 2004/38, cit. The specific situation of those having involuntarily lost employment or workseekers is discussed further below.

61 Art. 7, para. 1, let. b), of Directive 2004/38, cit.

62 As defined under Directive 2004/38, cit.: Pensionsversicherungsanstalt v Peter Brey, cit., paras $60-63$. 
person concerned".63 This amounts to requiring a case-by-case evaluation from the perspective of: (i) the national social assistance system; as well as, (ii) the specific situation of the individual, and keeping in mind, (iii) the specific nature of the benefits requested by the applicant. This case law seems to hold true, although the CJEU applied this test fairly strictly in the Dano case. ${ }^{64}$

In contrast, when more detailed guidance is provided in the form of a 'gradual system' the CJEU actually relies on the legislature's choices. ${ }^{65}$ In Alimanovic, the CJEU referred to and stuck to the gradual system established by the Directive: namely the retention of the status of 'worker' and the relevant conditions to retain the right to reside and be given access to social assistance. That included the duration of the exercise of any economic activity. ${ }^{66}$ The CJEU stressed that the advantage of such a scheme is to be unambiguous. As it is enshrined in legislation, it guarantees a significant level of legal certainty and transparency; and as it is gradual, it also complies with the principle of proportionality. ${ }^{67}$ The CJEU rejected further attempts to call into question the balance performed by the EU legislature between individuals' right to free movement, and the burden that mobile EU citizens who have lost their employment status may constitute on the national system of social assistance. ${ }^{68}$

The same approach was adopted in García-Nieto in relation to jobseekers; the Court re-asserted that the Directive provides a set of detailed and gradual rights. ${ }^{69}$ The CJEU may thus be ready to accept a rather inflexible system of allocation of rights if it is progressive and set in a way that ensures legal certainty and transparency. ${ }^{70}$ In that sense, the CJEU defers to political guidance and departs from its constitutional case law which provided more individualised solutions, but which were also less predictable. ${ }^{71}$

63 E.g. Pensionsversicherungsanstalt v Peter Brey, cit., para. 64, see also the detailed analysis of the interplay between different provisions of the Directive at paras $65^{-72}$ and 77 .

64 Elisabeta Dano and Florin Dano v Jobcenter Leipzig, cit., paras 81 and 83. Here the CJEU entitled a Member State to refuse to grant social benefits when the applicant exercise their right to freedom of movement solely in order to obtain social assistance: Elisabeta Dano and Florin Dano v Jobcenter Leipzig, cit., paras 76 and 78.

65 Jobcenter Berlin Neuköllnv Nazifa Alimanovic and Others, cit., paras 59-6o. See also Court of Justice, judgment of 11 April 2019, case C-483/17 Neculai Tarola $v$ Minister for Social Protection, paras. 43 and $45^{-}-57$.

66 Ibid., para. 6o.

67 Ibid., para. 61 .

68 Ibid., paras 60 and 62.

69 Vestische Arbeit Jobcenter Kreis Recklinghausen v Jovanna García-Nieto and Others, cit., paras $47-48$.

70 See Opinion of AG Wathelet, Coman, cit., para. 62.

71 Providing interesting analyses proposing to reconcile the old and new lines of cases: Davies, G. (2016). Migrants and Social Assistance: Trying to be Reasonable About 


\section{II.4 Interim Conclusion: Deconstitutionalisation}

Some have lamented that this novel approach constitutes a step backwards when compared to the early cases in which the CJEU developed a protective approach to equal treatment for EU citizens directly grounded in primary law. ${ }^{72}$ Critics point out that the post-Brey case law may have been triggered by fears of social tourism and Eurosceptic debates in several Member States. ${ }^{73}$ The point made here is more modest. This line of cases sheds light on the ability of the CJEU to reframe the interplay between primary and secondary law as well as between the judicial and political guidance. The post-Brey case law on access to social benefits provides a remarkable example of deconstitutionalisation following a period of intense constitutionalisation.

It may be added that the desire expressed in the UK Settlement from 2016 to "settle, in conformity with the treaties, certain issues raised by the United Kingdom in its letter of 10 November $2015,{ }^{\prime 74}$ sat comfortably with the post-Brey case law and in particular with the rulings in Dano (11 November 2014) and Alimanovic (15 September 2015). These cases indeed made it possible to accommodate the UK demands within the existing state of EU law and without there even being need for legislative reform. The UK Settlement recalled the wording of Art. $21 \mathrm{TFEU}$ referring to the limitations and conditions laid down, inter alia, in legislation. As allowed by the deconstitutionalisation process resulting from the aforementioned rulings, the right of non-economically active persons grounded in EU secondary law is dependent, among other things, on having sufficient resources for themselves and their family member. Member States can therefore refuse to grant social benefits to persons who exercise their right of movement solely in order to obtain social assistance if they do not have a right to residence under EU law. ${ }^{75}$

Self-Sufficiency. College of Europe Research Papers in Law, no. 2/2016 and Davies, G. (2018). Has the CJEU Changed or Have the Cases? The Deservingness of Litigants as an Element in CJEU of Justice Adjudication. Journal of European Public Policy 25 (10), pp. 1442-146o.

72 E.g. Shuibhne, N. N. (2015). Limits Rising, Duties Ascending: The Changing Legal Shape Of Union Citizenship. Common Market Law Review $5^{2}$ (4), p. 889.

73 E.g. Peers, S. (2014). Benefit Tourism by EU citizens: the CJEU Just Says No. EU Law Analysis, available at eulawanalysis.blogspot.com/2014/11/benefit-tourism-by-eu-citizens-cjeu.html.

74 Decision of the Heads of State or Government, meeting within the European Council, concerning a new settlement for the United Kingdom within the European Union, in Annex 1 of European Council Conclusions of 18-19 February 2016.

75 Exploring how this could impact a future agreement with the UK: Barnard, C., and Butlin, S.F. (2018). Fair movement of people: equal treatment? (Part Two). EU Law Analysis, available at eulawanalysis.blogspot.com/2018/o6/fair-movement-of-people-equal-treatment. html. 


\section{Constitutionalising the Perimeters of EU Citizenship Law: from Metock to Lounes, via the UK Settlement}

The relationship between treaty provisions, Directive 2004/38, related case law and the dialogue initiated by the UK Settlement took a different shape in relation to the rights of third-country national family members of mobile EU citizens.

\section{III.1 EU Legislation and the Rights Attached to EU Citizenship: from Singh to Akrich}

This second part of our story starts with the Surinder Singh ruling by the CJE U in 1992. The CJEU asserted that a national of a Member State might be deterred from leaving his country of origin if, on returning, the conditions of his entry and residence in his home State would constitute obstacles to his right of movement and establishment as provided in Arts 48 and 52 EECT at the time. ${ }^{76}$ This would be particularly so if children and spouses - nationals of a third country - were not permitted to enter and reside in the State of origin under conditions at least equivalent to those granted in the host country under secondary legislation available at the time. ${ }^{77}$

In Surinder Singh as well as in a number of subsequent cases, ${ }^{78} \mathrm{EU}$ free movement rules were relied upon to enhance the (albeit derived) rights of third-country national family members. The main feature of these cases was the CJEU's heavy reliance on the EU legislature's attachment to protecting the family life of mobile EU citizens. ${ }^{79}$ One question however was left unanswered: What if the third-country national family member has not yet been admitted, or is within the territory of the European Union without leave to remain before seeking to obtain a right to enter and stay as a family member of a mobile EU citizen? ${ }^{80}$

The answer came, in a less protective way than third-country national family members of a mobile EU citizen might have hoped for, in the Akrich ruling

76 Court of Justice, judgment of 7 July 1992, case C-370/9o, Surinder Singh, paras 19 and 23. Note that the same right can now be derived from Art. 21, para. 1, TFEU; Court of Justice, judgment of 12 March 2014, case C-456/12, O. and B., paras 48-49.

77 Surinder Singh, cit., paras 20-21.

78 For a more exhaustive overview see Cambien, N. (2011). Citizenship of the Union as a Cornerstone of European Integration: A Study of its Impact on Policies and Competences of the Member States, Doctoral Thesis, Faculty of Law, KU Leuven, p. 207 et seq.

79 E.g. Court of Justice, judgment of 25 July 2002, case C-459/99, MRAX, para. 53; Court of Justice, judgment of 14 April 2005, case C-157/o3, Commission v Spain, para. 26.

8o Opinion of AG Geelhoed delivered on 27 February 2003, case C-109/o1, Akrich, para. 7. 
from 2003. Here, prior lawful residence by the third-country national family member of an EU citizen in the EU state of origin was deemed to constitute a prerequisite for reliance on Art. 10 of Regulation 1612/68 on freedom of movement for workers, for the purpose of being able to claim residence rights against the state of origin. ${ }^{81}$ The regulation therefore was used to limit the rights of EU citizens to move with their third-country national family members. In the absence of prior lawful residence in the host state, the third-country national had no right under Regulation 1612/68 in the host state and could therefore claim no right "by analogy" under EU law in the state of origin. ${ }^{82}$ This approach was supported with reference to "the structure of Community provisions seeking to secure the freedom of movement for workers within the Community".83

\section{III.2 Ambiguities on the Sources of Rights: the Adoption of a New Legislative Framework and Revirement in Metock}

As is well known, the Akrich ruling was openly overruled in Metock. ${ }^{84}$ In the latter ruling, the CJEU made clear that the right of an EU citizen to move within the EU with a third-country national family member cannot depend on the prior lawful residence of such a family member in the EU. ${ }^{85}$ The CJEU explained its decision to reconsider the Akrich ruling ${ }^{86}$ with reference to political guidance taken from the text of the (then) new Citizenship Directive:87 the Directive does not distinguish between the status of various family members and entry to the territory of the host state must be possible even in the absence of a residence card. Furthermore, the Directive is understood as a tool that strengthens the right of free movement and residence of Union Citizens. ${ }^{88}$ This heavy emphasis on political guidance could have indicated that the rights of EU citizens to move to and reside freely in another Member State with their third-country national spouse - with no need for prior lawful residence - are enshrined in the Directive. ${ }^{89}$

Yet, the ruling in Metock is ambiguous on that point. On the one hand, the CJEU explains that the legislature has competence to regulate the conditions

\footnotetext{
81 Court of Justice, judgment of 23 September 2003, case C-109/o1, Akrich, para. 5 O.

82 Ibid., para. 54 .

83 Ibid., para. 51 .

84 Metock, cit., para. 58.

85 Ibid.

86 See for instance, Metock, cit., paras 55-57 on earlier case law of the CJEU as well as para 69 on the comparison with family reunification for third country nationals.

87 Ibid., paras 50-54.

88 Ibid., para. 59 .

89 See also Opinion of AG Maduro delivered on 11 June 2008, case C-127/08, Metock, para.13.
} 
for entry and residence of family members of EU citizens. ${ }^{90}$ On the other hand, in paragraph 62 (to which we will come back below), the CJEU stresses that "if Union citizens were not allowed to lead a normal family life in the host Member State, the exercise of the freedoms they are guaranteed by the Treaty would be seriously obstructed" (emphasis added). ${ }^{91}$ As a consequence, although the CJEU largely reasons on the basis of Directive 2004/38 throughout the ruling, the reference to treaty protection of the right to free movement suggests a constitutional anchorage of the possibility for EU citizens to move within the EU with third-country national family members irrespective of their prior lawful residence. The content of Directive 2004/38 on that point could thereby be subsumed in EU primary law. Importantly, and unlike in certain earlier cases, ${ }^{92}$ there is no statement from the CJEU in that ruling according to which such constitutional protection should be justified with reference to the fundamental right to family life. In fact, the case law of the European Court of $\mathrm{Hu}-$ man Rights focusing on the fundamental right to family life was in that sense less generous than that of the CJEU focusing on freedom of movement. The European Court of Human Rights indeed limited interferences into domestic migration policy on behalf of family life to exceptional family circumstances; it built on the assumption that family life may be possible in other States than the one refusing entry or residence. ${ }^{93}$

The important treaty provision referred to in Metock is Art. 21 TFEU as well as more specific treaty provisions for mobile economic actors. ${ }^{94}$ Before delving further into the role of Art. 21 TFEU in the subsequent UK Settlement, it shall be made clear that the CJEU has consistently held that EU citizens may not rely on Directive 2004/38 against their state of nationality - as will be the case in several cases discussed below - as the Directive applies to "Union citizens who move and reside in a Member State other than that of which they are nationals". ${ }^{95}$ However, Art. 21 TFEU protects the rights of mobile EU citizens to return to their country of origin. ${ }^{96}$ The CJEU traditionally applies the content of EU

\footnotetext{
$90 \quad$ Metock, cit., para. 61.

91 Ibid., para. 62.

92 I am most grateful to Jonathan Tomkin for pointing that out; eg. Baumbast, cit., para 72 and see further: Guild, E., Peers, S. and Tomkin, J. (2014). The EU Citizenship Directive: A Commentary. Oxford: Oxford University Press, p.133.

93 European Court of Human Rights, judgment of 2 August 2001, no. 54273/oo, Boultif v. Switzerland, paras $5^{2-55}$. See also Opinion of AG Geelhoed, Akrich, cit., para. 147. See further: Cambien, N. (2011). Citizenship of the Union, cit., p. 222.

94 Metock, cit., para. 61.

95 Art. 3, para. 1, of Directive 2004/38, cit.

96 This approach could already be observed in cases such as Surinder Singh, cit., paras 19-21.
} 
legislation on free movement "by analogy" to rule on the rights of returning EU citizens under Art. 21 TFEU. ${ }^{97}$ Nevertheless, as a consequence of the lack of clarity of the reversal of case law in Metock, it is not clear whether the entitlement of EU citizens to move freely with their third-country national family member with no prior lawful residence is derived from the content of Directive 2004/38 applied directly (in case of movement to a host Member State), or by analogy (in case of movement back to the Member State of nationality), or from Art. 21 TFEU per se.

\section{III.3 Shifting to Art. 21, Para. 1, TFE U: from the UK Settlement to Lounes}

The UK Settlement, as quoted in the Introduction, ignored (it may be presumed intentionally) the possible constitutional anchorage of the rights of third-country national family members. It built on the assumption that the solution in Metock was a matter of EU secondary law only. The UK Settlement proposed to address the challenge to EU law on that point through legislative intervention. The UK Settlement indeed included a declaration by which the European Commission intended to adopt a proposal to "complement" Directive 2004/38.98 The proposal to have been supported by the Member States within the Council would have been intended to undo the Metock ruling. Indeed, a new instrument would be proposed in order to "exclude, from the scope of free movement rights, third country nationals who had no prior lawful residence in a Member State before marrying a Union citizen, or who marry a Union citizen only after the Union citizen has established residence in the host Member State". ${ }^{99}$ The UK Settlement thereby built on the assumption that reversing Metock could be achieved through legislative intervention. It was hoped that the European Parliament, as a co-legislator, would support this initiative.

Yet, in the Lounes case from $2017,{ }^{100}$ the CJEU adopted a different reading of its ruling in Metock. Ms Ormazabal, a dual national from Spain and the UK, sought to derive a right of residence in the UK for her husband from her EU citizenship status. The latter, Mr Lounes, was not lawfully residing in that country

97 See also early cases such as Court of Justice, judgment of 11 December 2007, case C-291/ o5, Eind, paras 39-45.

98 This was perhaps deemed as less difficult than re-opening a full negotiation of Directive 2004/38 in the near future: see for instance the more distant proposal made "on the occasion of a future revision of Directive 2004/38" in relation to the notions of public policy and public security (Annex 7, of European Council Conclusions of 18-19 February 2016).

99 Annex 7 of European Council Conclusions of 18-19 February 2016.

100 Court of Justice, judgment of 14 November 2017, case C-165/16, Lounes. 
at the time of their marriage. ${ }^{101}$ Ms Ormazabal, in the view of the CJEU, could not rely on Directive 2004/38. Although she had moved from Spain to the UK in her capacity as a Spanish national, she had subsequently acquired British citizenship before marrying Mr Lounes. The UK had thereby become her country of nationality ${ }^{102}$ and she had an unconditional right of residence in the UK under international law.103

Although she could not rely on EU secondary law against her country of nationality, the CJEU found that Ms Ormazabal could rely on Art. 21, para. 1, TFEU. While in the past, similar findings were based on the risk of hindering the freedom of movement of EU citizens, ${ }^{104}$ the CJEU here reasoned that "[a] national of one Member State who has moved to and resides in another Member State cannot be denied that right merely because he subsequently acquires the nationality of the second Member State in addition to his nationality of origin, otherwise the effectiveness of Article 21(1) TFEU would be undermined".105 The CJEU then went on to substantiate this finding. ${ }^{106}$

Leaving aside aspects of the rulings related to the specific case of mobile EU citizens acquiring the nationality of the host state and possibly related to the Draft Withdrawal Agreement ${ }^{107}$ (as discussed elsewhere by Davies), ${ }^{108}$ what is of particular interest in this chapter is the anchorage of Ms Ormazabal's rights in Art. 21, para. 1, TFEU. These rights of EU citizens include "the right to lead a normal family life, together with their family members". 109 To support that finding, the CJEU reasoned by analogy to paragraph 62 of the ruling in Metock. ${ }^{110}$ The CJEU insisted that for the rights conferred by Art. 21, para. 1, TFEU to be effective, citizens in a situation such as Ms Ormazabal must continue to enjoy the right to "build a family life with their third-country-national

\footnotetext{
101 Ibid., para. 16.

102 See supra, Eind, cit.

103 Lounes, cit., paras 37 and 41.

104 As acknowledged by the CJEU in Lounes, cit., para. 48. See also supra, Surinder Singh, cit.

105 Lounes, cit., para. 53.

106 Ibid, paras 54-59.

107 Art. 9, of European Commission (2018). Draft Agreement on the withdrawal of the United Kingdom of Great Britain and Northern Ireland from the European Union and the European Atomic Energy Community, $\mathrm{TF}_{5} \mathrm{O}$ (2018) 35 - Commission to EU27.

108 For an analysis of other aspects of the ruling in the context of Brexit see Davies, G. (2018). Lounes, Naturalisation and Brexit. European Law Blog, available at europeanlawblog. eu/2018/o3/o5/lounes-naturalisation-and-brexit/. That discussion relates to mobile EU nationals having acquired the nationality of the host state, that aspect of the ruling is therefore beyond the scope of the current paper.
}

109 Lounes, cit., para. $5^{2}$.

110 Ibid., para. $5^{2 .}$ 
spouse, by means of the grant of a derived right of residence to that spouse" under that provision. ${ }^{111}$ Although there is no explicit reference to the lack of prior lawful residence, the ruling in Lounes can be read as bringing an end to the ambiguity created by paragraph 62 in Metock.

\section{III.4 Interim Conclusion: Constitutional Protection?}

The rights of EU citizens to be with their family members from a third country in the host state, irrespective of the absence of prior lawful residence - as the facts of both Metock and Lounes indicate - would thereby be anchored in Art. 21, para. 1, TFEU. This approach implies that disagreement on the scope of free movement rights for EU citizens with third-country nationals with no prior lawful residence in a Member State cannot be addressed without treaty reform, contrary to the underlying logic of the proposal in the UK Settlement.

However, the ruling in Lounes replaces one ambiguity with another. Although that ruling is mostly structured around Art. 21, para. 1, TFEU, the CJEU concludes its reasoning in paragraph 61 by stating that the conditions for granting a derived right of residence to the third-country national spouse should not be stricter than those provided in Directive 2004/38, and that the Directive should be applied "by analogy".12 This suggests that although the rights of EU citizens such as Ms Ormazabal are anchored in Art. 21, para. 1, TFEU, the CJEU puts flesh on the bones of EU primary law with the political guidance enshrined in EU legislation. This raises the following questions: Would a modification of EU legislation (or other legal instrument of the EU ranking beyond primary law) favourable to domestic migration policies lead to a change of case law in a case such as Metock or Lounes? Or would the legislation be found to breach the constitutional right of EU citizens to move with their family members, even in the absence of prior lawful residence in a Member State?

\section{Soul Searching: Acknowledging the Political Dimension of EU Citizenship Law and Locating the Debate at Legislative Level}

The analysis of the first set of rights - access to social benefits for noneconomically active persons - showed how the CJEU reframed its initial approach grounded in EU constitutional provisions in order to discuss such rights in the context of Directive 2004/38. To the contrary, the analysis of the second

\footnotetext{
111 Ibid., para.6o.

112 Ibid., para. 61.
} 
set of rights - of third-country national family members of an EU citizen with no prior lawful residence - has shown that this set of rights is seemingly being elevated to EU primary law. The practical outcome of these divergent processes is usefully illustrated with reference to the UK Settlement: while controversies to do with the first set of rights could be addressed with reference to the legislation, as things currently stand, controversies related to the second set of rights could presumably not be addressed through legislative change. How can we reconcile or coherently articulate these two approaches?

\section{IV.1 Art. 21, Para. 1, TFE U and Directive 2004/38: the Directive as a Gateway to EU Primary Rights?}

As noted in Section II, the recent case law of the CJEU on access to social benefits for non-economically active persons espouses the structure of Directive $2004 / 38$ and acknowledges that the Directive acts as a gateway to equal treatment rights for EU citizens in the host State. In contrast, Section III pointed at the possibility that the rights derived by third-country nationals with no prior residence from EU citizens are being anchored directly in Art. 21, para. 1 , TFEU - although the wording of paragraph 61 of the ruling in Lounes leaves open the possibility of articulating the relationship between Directive 2004/ 38 and the primary right differently. It is submitted that, as far as the rights of EU citizens to move with third-country national family members with no prior lawful residence are concerned, Directive 2004/38 should remain the main point of reference to define the scope of the rights of EU citizens - be it "by analogy". 113

This would allow discontent to be addressed through political dialogue as was proposed by the UK Settlement. This would also allow the approach of the CJEU in relation to third-country national family members to be brought closer to that adopted in the cases on social benefits examined above, while keeping in line with the European Court of Human Rights' approach to the fundamental right to family life. ${ }^{114}$ This would finally allow for a better alignment of the related case law with the general approach of the CJEU as it has been shaping up over the past few years in other areas of EU citizenship law related to Art. 21 TFEU.

113 See for instance Court of Justice, judgment of 12 July 2018, case C-89/17, Secretary of State for the Home Department $v$ Rozanne Banger, paras 29 et seq. Exploring the limits of reasoning by analogy, where requested by the wording of Directive 2004/38 itself, see Court of Justice, judgment of 10 September 2019, case C-94/18, Nalini Chenchooliah v Minister for Justice and Equality, paras 71-88.

114 See for instance Akrich, cit., paras 58-6o. 
The CJEU is indeed increasingly consistently ${ }^{115}$ using Directive 2004/38, and its Art. 7 in particular, as a gateway to access EU citizenship rights when the two layers of norms can inform each other. (Understandably, this has not been done in the context of rights anchored directly in treaty provisions and where the provisions of EU legislation were irrelevant). ${ }^{116}$ Useful recent examples are the three Grand Chamber rulings in O. and B., Marin and Chavez-Vilchez. ${ }^{117}$ In $O$. and $B$., the CJEU investigated the ability of EU citizens to derive rights for third-country national family members in their country of origin from the exercise of the freedom of movement. Although such rights would be anchored in Art. 21, para. 1, TFEU - as the Directive cannot be relied upon against the state of origin - the CJEU firmly asserted that the provisions of Directive 2004/ 38 would act as a gateway to Art. 21, para. 1, TFEU. ${ }^{118}$ Directive 2004/38 was being applied by analogy ${ }^{119}$ but with a detailed analysis of its provisions. ${ }^{120}$ Indeed, for rights to be derived from the treaty, it is necessary that "residence of the Union Citizen in the host Member State has been sufficiently genuine so as to enable that citizen to create or strengthen family life in that Member State". ${ }^{21}$ For that purpose, "[r]esidence in the host Member State pursuant to and in conformity with the conditions set out in Art. 7(1) of that directive is, in principle, evidence of settling there and therefore of the Union citizen's genuine residence in the host Member State, and goes hand in hand with creating and strengthening family life in that Member State". ${ }^{122}$ In contrast, residence

115 E.g. Court of Justice, judgment of 19 October 2004, case C-20o/o2, Zhu and Chen, paras 27-28 and 46; Eind, cit., paras 39-40; Court of Justice, judgment of 10 October 2013, case C-86/12, Alokpa, paras 29-30.

116 See for instance Art. 20 TFEU and the case law developed on the basis of the ruling in Zambrano, cit. In such cases though, there is very limited space for dialogue - to which this contribution is devoted - between European key players on the content of the rights. There are also naturally cases in which EU citizenship law is not applicable; e.g. Court of Justice, judgment of 8 November 2012, case C-40/11, Yoshikazu Iida $v$ Stadt Ulm, paras 73 et seq. or judgment of 25 July 2018 , case C-679/16, $A$. It is acknowledged that there also exist situations where Art. 21, para. 1 TFEU cannot be used in conjunction with EU legislation. For recent examples see Court of Justice, judgment of 10 April 2018, case C-191/16, Pisciotti and judgment of 13 November 2018, case C-247/17, Denis Raugevicius.

117 See also for instance the ruling by the Court of Justice, judgment of 30 June 2016, case C$115 / 15, N A$, para. 78 .

118 See also Spaventa, E. (2015). Family Rights for Circular Migrants and Frontier Workers: O and B, and S and G. Common Market Law Review $5^{2}$ (3), pp.753-777, 767 and 769.

119 O. and B., cit., para. $5^{\circ}$.

120 See also: Court of Justice, judgment of 27 June 2018, case C-230/17, Erdem Deha Altiner and Isabel Hanna Ravn $v$ Udlaendingestyrelsen, paras 27 et seq.

121 O. and B., cit., para. 51.

122 Ibid., para. 53 . 
under Art. 6, para. 1, would not be enough. ${ }^{123}$ The CJEU insists that the conditions in Art. 7, paras 1 and 2, of Directive 2004/38 must be met for the effectiveness of the right of the EU citizen, under Art. 21, para. 1, TFEU, to return with a family member who is a third-country national to be protected. ${ }^{124}$ This applies a fortiori for residence pursuant to Art. 16, paras 1 and 2, of Directive 2004/38. ${ }^{125}$

This approach of using Directive 2004/38 as a gateway to Art. 21, para. 1, TFEU is further exemplified by the CJEU's efforts to rephrase preliminary questions raised by domestic courts so as to articulate its reasoning with reference to both Art. 21, para. 1, TFEU and Directive 2004/38. The case in Marín concerned the residence rights in Spain of a third-country national who was primary carer of two children, one with Spanish nationality, the other with Polish nationality. Although the domestic court asked the CJEU for guidance on Art. $20 \mathrm{TFEU}, 126$ the CJEU rephrased the question so as to be able to start the analysis with an examination of Art. 21 TFEU and Directive 2004/38. ${ }^{127}$ The Polish nationality of the daughter living in Spain brought her within the personal scope of Directive 2004/38. ${ }^{128}$ The CJEU derived from this observation that the daughter was therefore entitled to "rely on Article 21(1) TFEU and the measures adopted to give it effect"129 and, therefore, that her right to reside in Spain was in principle conferred by Art. 21, para. 1, TFEU and Directive 2004/38. ${ }^{130} \mathrm{Hav}$ ing acknowledged that the two provisions had to be read in conjunction, the CJEU went on to check if the conditions contained in the Directive were met with a particular focus on whether the daughter fulfilled the conditions under Art. 7, para. 1, let. b), of the Directive. ${ }^{131}$ That provision was therefore used as a gateway to EU citizenship rights. ${ }^{132}$ The CJEU further relied on Directive

123 Ibid., paras 52 and 59. The CJEU also secures the role of Art. 7 of Directive 2004/38 as an entry point by rejecting arguments based on the recognition of a residence card given by the host state to the third country national in the absence of a right derived from the EU citizen (para. 6o). Furthermore, the third-country national must have been a family member in the host state before being able to indirectly derive rights from the EU citizenship through Art. 21, para. 1 TFEU and using Directive 2004/38 by analogy (para. 63).

124 O. and B., cit., para. 54 .

125 Ibid., para. 55 .

126 Court of Justice, judgment of 13 September 2016, case C-165/14, Marín, para. 23.

127 Ibid., paras 34-35.

128 Ibid., para. 41 .

129 Ibid., para. 43.

130 Ibid., para. 44.

131 Ibid., para. 46.

132 This is particularly clear at: Marín, cit., para. $5^{2}$. See also: Court of Justice, judgment of 2 October 2019, case C-93/18, Ermira Bajratari $v$ Secretary of State for the Home Department, paras 26, 28-29 although Article $21 \mathrm{TFEU}$ is also mentioned at paras 42 and 47 to shed light on the broader context in which Directive 2004/38 ought to be interpreted. 
$2004 / 38$ to examine the derived rights of the third-country national family member. ${ }^{133}$

The Chavez-Vilchez judgment also provides an illustration of the Grand Chamber of the CJEU's efforts to articulate the relationship between Art. 21, para. 1, TFEU and Directive 2004/38 in a similar way. The case arose from eight disputes surrounding the residence rights of third-country nationals who were primary carers of children in the latter's country of nationality. Once again, although the domestic court asked for guidance on Art. 20 TFEU, the CJEU brought Art. 21 TFEU and Directive 2004/38 as a preliminary point for analysis for the one child who had exercised his free movement right. ${ }^{134}$ The child had then returned to the country of nationality and Directive 2004/38 could not therefore apply as such; instead Art. 21, para. 1, TFEU would apply and the content of the Directive would be applied by analogy. 135 The CJEU then emphasised that the national court would therefore have to check if the conditions listed under Arts 5 to 7 of Directive 2004/38 were fulfilled before the child could claim derived rights from Art. 21, para. 1, TFEU and Directive 2004/38 for her third-country national carer. In other words, once again, the provisions of Directive $2004 / 38$ were used as a gateway to EU citizenship rights. ${ }^{136}$

These cases illustrate not only that Art. 21 TFEU shall be given priority over Art. $20 \mathrm{TFEU}$, but also that Directive 2004/38 acts as an entry point to primary EU citizenship rights, even when the Directive is only applied by analogy, as in $O$. and B. and Chavez-Vilchez regarding returning EU citizens. This is precisely what the design of the treaty provisions call for by referring to the limitations and conditions defined in instruments adopted thereupon. This approach does not neglect the requirement for legislation to comply with primary law and fundamental rights such as the fundamental right to family life, this remains a pre-condition for the validity of EU secondary law. Nor does this approach prevent direct reliance on Art. 21, para. 1, TFEU. ${ }^{137}$ It is more modestly argued that when legislation co-exists with primary rights, reliance on guidance enshrined in legislative instruments makes it possible to more easily address accusations

133 Marín, cit., paras 54, 57, 62 and 67. It may be noted that the reasoning on limitations to EU citizenships rights granted by Art. $20 \mathrm{TFEU}$ in that case also seems to be strongly inspired from the content of Directive 2004/38 although the Directive is not explicitly mentioned. See also Court of Justice, judgment of ${ }_{13}$ September 2016, case C-304/14, CS, para. 36 et seq. The author is grateful to Stephen Coutts for pointing that out.

134 Court of Justice, judgment of 10 May 2017, case C-133/15, Chavez-Vilchez, paras 49-50.

135 Ibid., paras 54-55.

136 This is particularly clear at: Marín, cit., para. 56 .

137 Baumbast, cit., para. 86. 
of over-constitutionalisation of EU law and empowers actors to address challenges through political dialogue.

It is therefore suggested that, following the trend initiated by the post-Brey case law in relation to social benefits, the relationship between Art. 21 TFEU and Directive 2004/38 in the context of claims in favour of third-country national residents with no prior lawful residence could be clarified by placing stronger emphasis on legislative guidance. The constitutional status of EU citizenship would thereby be present and recognised with reference to Art. 21, para. 1, TFEU, but the precise scope of the rights at hand would rely on stronger political guidance that could be modified in case of disagreement subject to compliance with higher norms such as the fundamental right to family life as understood by the European Court of Human Rights.

It is in light of this last caveat on fundamental rights' compliance that the recent ruling in Coman ${ }^{138}$ may be understood and reconciled with the approach proposed in this chapter. The Grand Chamber of the CJEU was asked several questions on Directive 2004/38, as well as the Charter. ${ }^{139}$ The national court asked for guidance on the possibility of a mobile EU citizen returning to his home country with a third-country national whose status as a family member was unclear. Indeed, the same-sex couple had lawfully married in Belgium but same-sex marriage is not recognised by the Member State of origin of the EU citizen where the couple now wants to return. Once again, the CJEU reframed the dispute and focused on Art. 21 TFEU as well as Directive 2004/ 38 applied by analogy to the situation of a returning EU citizen. ${ }^{140}$ The CJEU initially examines the term of "spouse" enshrined in Directive 2004/38 to conclude that national law cannot exclude same-sex couples lawfully married in another Member State "for the sole purpose of granting a derived right of residence to a third-country national". ${ }^{141}$ While this first part of the ruling answers the call for emphasis on legislative instruments expressed above, ${ }^{142}$ the CJEU then moves on to examining the domestic measure restricting the EU citizen's mobility in light of Art. 21 TFEU. ${ }^{143}$ This shift towards a constitutional level of protection of the right is surprising in light of the cases discussed above

\footnotetext{
138 Court of Justice, judgment of 5 June 2018, case C-673/16, Coman.

139 Ibid., para. 17.

140 Ibid., paras 18-27.

141 Ibid., para. 36 .

142 This is irrespective of the details of the CJEU's analysis of the actual wording of the Directive. See further Opinion of AG Wathelet, Coman, cit., paras 43-76.

143 Coman, cit., paras 40 et seq. Note the interesting reference to national identity, which is beyond the scope of this contribution, at paras $42-46$.
} 
which were more exclusively focused on Directive 2004/38. Yet, reference to the constitutional rights of EU citizens can be understood with reference to the fundamental right to family and private life of same-sex couples that may under specific circumstances be protected in the same way as that of heterosexual couples in similar situations as recognised by the European Court of Human Rights. ${ }^{144}$

\section{IV.2 Concluding Remarks on the Relationship between Primary and Secondary Rights}

Looking beyond the cases discussed so far, several broader lessons can be drawn from the post-Brey and post-Metock case law as regards the role of key EU actors in shaping the contours of EU law. To come back to the initial concerns against the over-constitutionalisation of EU law, the post-Brey cases illustrate that the CJEU may be ready to engage in deconstitutionalisation processes, to thereby make more space for political dialogue. What influences the readiness of the EU judiciary to adopt such an approach? Several important factors in the hands of the drafters of the Treaty and EU political institutions can be identified.

Firstly, in the cases discussed above, the wording of the relevant treaty provisions clearly identified the need for further political guidance. As the CJEU itself observed in Dano: (i) Art. 18, para. 1, TFEU prohibits any discrimination on grounds of nationality " $[\mathrm{w}]$ ithin the scope of application of the treaties, and without prejudice to any special provisions contained therein"; (ii) the second subparagraph of Art. 20, para. 2, TFEU expressly states that the rights conferred on EU citizens by that article are to be exercised "in accordance with the conditions and limits defined by the Treaties and by the measures adopted thereunder", and; (iii) under Art. 21, para. 1, TFEU the right of EU citizens to move and reside freely within the territory of the Member States is subject to compliance with the "limitations and conditions laid down in the Treaties and by the measures adopted to give them effect". ${ }^{145}$ All key treaty provisions thus call for further political guidance.

Secondly, and importantly, the secondary legislation relied upon in the deconstitutionalisation process described above has a strong organic link with the relevant treaty provisions (Arts 18, 20 and $21 \mathrm{TFEU}$ ). Arts 18 and $21 \mathrm{TFEU}$

144 Coman, cit., paras 48 (Charter) and 50 (European Court of Human Rights). See in particular European Court of Human Rights, judgment of 14 December 2017, nos. 26431/12, $26742 / 12,44057 / 12$ and 60o88/12, Orlandi and others $v$. Italy. The Court of Justice does not however elaborate further on its approach to the fundamental rights at hand.

145 Elisabeta Dano and Florin Dano v Jobcenter Leipzig, cit., para. 6o. 
count among the legal bases for Directive 2004/38. ${ }^{146}$ Furthermore, Art. 24 of Directive 2004/38 constitutes a specific expression of the principle of nondiscrimination laid down generally in Art. $18 \mathrm{TFE} \mathrm{EU}^{147}$ for the benefit of EU citizens (as defined in Art. $20 \mathrm{TFEU}$ ), who exercise their right to move by virtue of Art. 21 TFEU. This organic link may make it easier for the judiciary to shift from one level of analysis to the other; that is from primary to secondary law. Now, this observation can work the other way around as illustrated by the ambiguities created by the rulings in Metock and Lounes examined above. It is submitted that, when treaty provisions and legislative guidance co-exist, emphasis shall be placed on the latter.

Thirdly, the CJEU places specific emphasis on the quality of the legislative materials it is relying upon and deferring to. In cases such as Alimanovic and García-Nieto, the CJEU indeed endeavours to highlight the progressive (and thus presumably proportionate) nature of the system of allocation of rights under Directive 2004/38; it also stresses the unambiguous wording that ensures transparency and legal certainty. ${ }^{148} \mathrm{~A}$ similar emphasis on the gradual approach enshrined in Directive 2004/38 is clear from the $O$. and B. case. The CJEU emphasised the link between settling in another Member State in accordance with Art. 7 of Directive 2004/38 - and a fortiori under Art. 16 (permanent residence after five years) of that instrument - and creating and strengthening family life in that same Member State. ${ }^{149}$ On the contrary, the absence of an intention to settle when movement is based on Art. 6 of Directive 2004/38 (residence of less than three months) excludes the possibility of residence that would be "sufficiently genuine so as to enable that citizen to create or strengthen family life in that Member State". ${ }^{150}$ Importantly, in establishing the gradual system in Directive 2004/38, and on which the Lounes case also insists, ${ }^{151}$ the EU legislature made the policy implications of its choices sufficiently clear for the Court to be willing to defer to it. Critics of the system established by the Directive may then argue for changes in the legislation itself.

This analysis of the respective role of the drafters of the treaty, the EU's judicial, and political institutions in shaping EU citizenship law therefore sheds light on three elements that determine the pre-conditions for a healthy

146 Recital 1, of Directive 2004/38, cit. (note that the numbering of Treaty articles mentioned herein is pre-Lisbon).

147 Elisabeta Dano and Florin Dano v Jobcenter Leipzig, cit., para. 61.

148 See supra, n. 65 et seq.

149 O. and B., cit., paras $55^{-} 56$ and 59 .

$15^{\circ}$ Ibid., paras $5^{1}$ and 59 .

$15^{1}$ Lounes, cit., paras $56-57$. 
balance between the constitutional value of the relevant right, and the political dimension of decision-making on fundamental rights: the constitutional norm itself ought to explicitly call for political guidance. Building on such a constitutional mandate, political institutions ought to achieve a fine balance between acknowledging the existence of the constitutional right and giving it shape through legislation. It is submitted that this may be best done by asserting the policy implications of decision-making in the field and the policy arguments justifying choices made in EU legislation. Furthermore, the internal coherence, clarity and nuanced nature of the rights thereby regulated will make it easier for political guidance to be deferred to. As for the judiciary, when the constitutional framework is clear and the relevant political guidance fulfils the procedural requirements set therein, it may be encouraged to defer to that legislative framework. 